(C) Pishchal'nik V.M., Truskov P.A., Solomatin S.V., Romanyuk V.A., Leonov A.V., 2019, Океанологические исследования, 2019, Том 47, № 4, С. 88-105

УДК $551.467 .3(265.53)$

DOI: 10.29006/1564-2291.JOR-2019.47(4).6

\title{
ANALYSIS OF THE CONDITIONS IN THE FORMATION OF OPEN WATER SPACES BEHIND OFFSHORE PLATFORMS FOR THE ELIMINATION OF OIL SPILLS
}

\author{
Pishchal'nik V.M. ${ }^{1}$, Truskov P.A. ${ }^{2}$, Solomatin S.V. ${ }^{2}$, Romanyuk V.A. ${ }^{3}$, \\ Leonov A.V. ${ }^{4}$
}

${ }^{1}$ Sakhalin State University; 290, Lenin Street, Uzhno-Sakhalinsk, 693008, Russia e-mail:vpishchalnik@rambler.ru

${ }^{2}$ Sakhalin Energy Investment Company Ltd; 31, Novinslij Bulvar

Moscow, 123242, Russia,

${ }^{3}$ OOO «PH-SakhalinNIPImorneft'»; 53, Amurskaya Street, Uzhno-Sakhalinsk, 693000, Russia ${ }^{4}$ Shirshov Institute of Oceanology, Russian Academy of Sciences, 36 Nahimovskiy prospekt, Moscow, 117997, Russia,

Submitted 15.08.2019, accepted 21.11.2019

\begin{abstract}
The first marine ice-resistant stationary platform Pil'tun-Astokhskaya-A (MISP PA-A) was installed on the northeast shelf of Sakhalin Island more than 20 years ago. Currently, five MISPs (PA-A, PA-B, LUN-A, Orlan and Berkut) operate in the coastal waters and plans are being actively discussed to develop new hydrocarbon deposits. The duration of the ice period in this region of the Sea of Okhotsk varies from 181 to 197 days, and the issue of actions plans for the elimination and mitigation of possible large-scale oil spills in the ice period are of particular relevance.

This paper presents the results of the study of the conditions for the formation of open water spaces (OWS) in the ice cover (IC) behind the MISP obtained from aeronautical, shipbased and satellite observations, as well as practical experience in ice management in the framework of the Sakhalin-2 project in 1999-2008. The peculiarities of OWS formation can be refined for significant increasing of response on the oil pollution in the presence of the IC, for example, by eliminating oil in the wake formed by ice drift after the MISP and therefore reduce the load on the marine environment. The proposed methodological approach of artificially created OWS can be implemented in the waters of the freezing and Arctic seas that wash the shores of Russia, where the development of offshore hydrocarbon deposits is underway. At the same time, special attention for each particular MISP should be given to taking into account local ice conditions when developing safety issues for conducting such marine operations (this issue should be the subject of a separate study).
\end{abstract}

Keywords: open water spaces, seasonal ice cover, ice conditions, ice phases, satellite imagery, effectiveness of response to oil pollution of the sea water in the presence of ice cover

\section{Source data and methods for their processing}

The basis for calculating the performance characteristics of the IC was the collection of color-codified map-schemes of Japan Meteorological Agency (JMA) for 1998-2018, posted on the JMA website (http://www.data.jma.go.jp). Since 1998, the development 
of the charts has been carried out annually from the beginning of November to July inclusive with the pentad discreteness (once every five days). On this basis, it is possible to determine the dates of the beginning and the end of the ice season, the location of the ice edges and the boundaries of the IC with different ice concentrations, to calculate the particular and total area of the IC. The inaccuracy in calculating the IC area does not exceed 2\% from the sea area covered with the ice (Pishchal'nik et al., 2016). Seasonal values of the IC for different years were calculated as the average for the period from December to May.

For the expert control of the calculated data and the assessment of the ice situation we used the archives of images of the visible range from the satellites Terra-MODIS, Sentinel-1, Sentinel-2, Suomi NPP, posted on the websites (https://worldview.earthdata. nasa.gov; https://apps.sentinel-hub.com), as well as personal collections of images and ice observations of the authors of this paper. To process the color-coded map-schemes, the software complex ("LYOD" PC) was used, which was applied to calculate the IC areas within of the entire Sea of Okhotsk, taking into account ice concentration, and of some its areas with arbitrarily specified boundaries (Svidetel'stvo ..., 2015; Romanyuk et al., 2015).

The typization of winters according to the severity of ice conditions was made according to the formula of Yu.P. Doronin (1959). The moderate type of winters includes winters with seasonal IC, $L_{i}$, lying in the interval $L_{a v} \pm(1 / 6) \times \mathrm{A}$, where, $j$ is the index of the year; $\mathrm{A}$ is the amplitude of the change in the characteristic value, $L_{a v}$ is the average value of the total IC during the observation period. The types of harsh and mild winters include winters with $L_{j}>L_{a v}+(1 / 6) \times \mathrm{A}$ and $L_{j}<L_{a v}-(1 / 6) \times \mathrm{A}$, respectively.

The spatial dimensions of the studied water area around the MISP PA-A and PA-B are $15 \mathrm{~km}$ in latitude and $30 \mathrm{~km}$ in longitude, which corresponds to the gradation of "synoptic processes" according to the classification of non-stationary processes in the ocean. Their time scale varies from a day to a dozen days (a month), and a spatial one varies from 1 to $10^{2} \mathrm{~km}$ (Monin et al., 1974). However, to make adequate decisions on accounting for ice conditions in the studied water area, it is essential to know and take into account the variability of the desired characteristics in the waters of the north-western region of the Sea of Okhotsk, which is the main ice generation area in its western half. For this purpose, comparative analysis of the variability of the main characteristics of the ice regime for the studied water area of $450 \mathrm{~km}^{2}$ and the northwestern region with an area of 432.3 thousand $\mathrm{km}^{2}$ was performed (Minervin et al., 2015).

\section{Characteristic features in the processes of ice formation}

The main factor influencing the intensity of ice generation and IC in the Sea of Okhotsk is the activity of the winter monsoon, which not only delivers cold air masses to the sea from the continent, but also causes general ice drift into the southern directions. During the monsoon period (from the beginning of November to mid-April), ice is being generated continuously and the direction and speed of ice drift (in addition to regular oscillations caused by tidal currents) occasionally briefly changes under the influence of the southern 
and eastern rhythms on the IC during the passage of deep baric formations (Romanjuk et al., 2011). The zone of influence of baric formation on the ice massif is determined by its horizontal dimensions, as well as the trajectory and character of its movement over the water area of the Sea of Okhotsk and can vary from several tens to several hundred kilometers, and in terms of time exposure - from several hours to several days.

Ice formation processes along the East coast of Sakhalin Island begin in late of November and early December. As the temperature of air and water decreases, the ice formation first occurs in the shallow and most desalinated zones at the junction points of eastern Sakhalin and the sea (Fig. 1). The formed initial types of ice, under the influence of the north-west wind and the East-Sakhalin Current that is developed the most at this time of the year, drift eastward and southward, and the new ice forms in its place (Fig. 2) (Pishchal'nik et al., 2017).

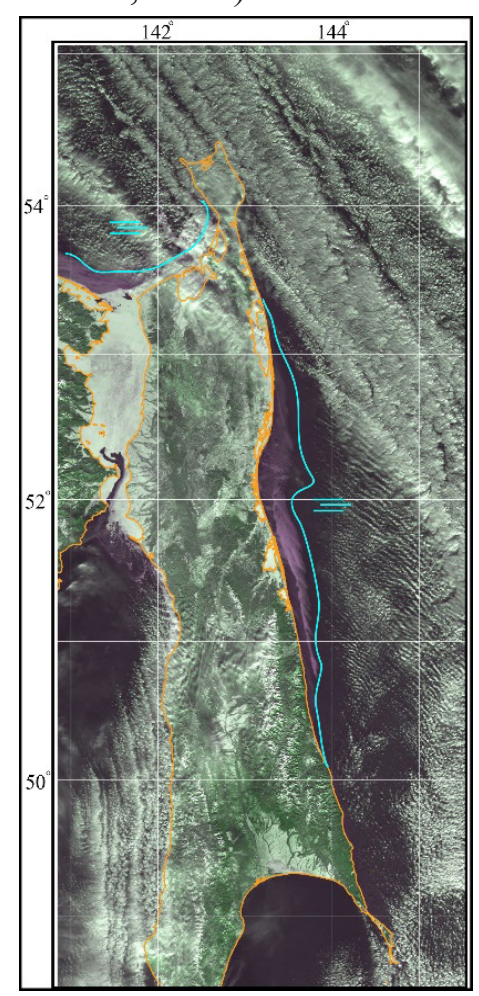

Fig. 1. The first appearance of ice on the northeast coast of the Sakhalin Island. Snapshot for 12.10.2018.

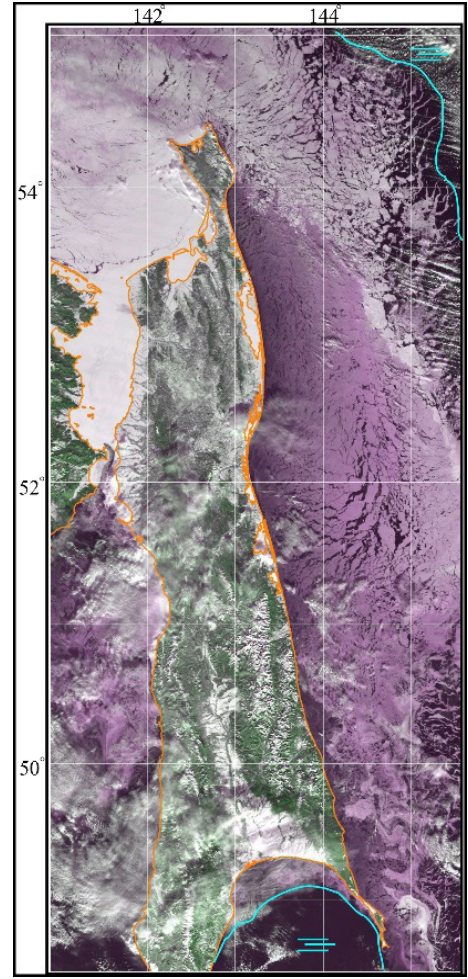

Fig. 2. The initial stage of the formation of a polynya at the end of December.

Photo taken on 12.23.2017. Blue line -is the ice edge.

In early January, the array of initial types of the ice along the eastern border is contoured by the older ice belt, which is formed in the natural ice trap in the Sakhalin Bay water area (Fig. 2). Ice in the bay lingers on for a long time (up to 1-3 months or more), while its thickness rapidly increases under the influence of both thermal and dynamic factors as a result of multiple layering and subsequent freezing of ice. After the Sakhalin Gulf is completely filled with ice, its surpluses during siggy periods of spring tides are portioned out of the bay to the east coast and, being included in the general ice drift, are displaced at a certain distance from the coast in the southeast direction, forming the 
eastern border of the coastal polynya filled with initial ice. According to satellite and instrumental observations, the average drift velocity of the IC along the polynya boundary between $51-54^{\circ} \mathrm{N}$ is $5-10$ miles/day, while the maximum drift speed can exceed 50 miles/day (Pokrashenko et al., 1987; Astafyev et al., 1997; Pishchal'nik et al., 2009).

In February, the ice drifting from the north-western part of the Sea of Okhotsk turns into one-year ice and its area increases significantly. Thus, array of heavy ice forms along the eastern coast of Sakhalin Island. Coastal polynya is maintained until the beginning of the weakening of the winter monsoon. The width of the polynya is determined by the intensity of the atmospheric circulation and varies from 30-40 to 80-90 miles. It should be noted that in case the cyclone trajectory crosses Sakhalin Island, then at any stage of the IC development from December to May under the influence of the winds of the East Rumba, short-term drift of ice to the coast with its subsequent substantial deformation and partial or full short-term polynya closure is possible.

After the monsoon changes direction, usually by mid-April, array of very concentrated one-year thin ice (30-70 cm thick) with inclusions of up to 2-3 points of zones of one-year average ice (70-120 cm thick) closely approaches the shore. During the passage of cyclones, short-term polynya formation is possible, which again is quickly filled with initial types of ice according to the pattern described above. Active thermal destruction of ice begins in May, and the final purification of the water area of the North-eastern shelf Sakhalin Island from the ice occurs in June.

\section{Analysis of the results of the calculated data}

3.1. Dates of the start and the end of the ice seasons

During the study period, the first IC appearance in the water area of the Pil'tunAstokhskoye field on average was observed on November 28, with fluctuation limits of November 20 to December 10. Complete cleansing of the area from ice occurred on June 8 (the earliest purification - May 20, at the latest - June 25). The average duration of the ice period is 192 days, the minimum is 181 , and the maximum is 197 days (Table 1).

Table 1 Dates of the onset of ice phases in the waters of the Pil'tun-Astokhskoye field in the period of $1998-2018$

\begin{tabular}{|c|c|c|c|}
\hline Dates & Appearance & Disappearance & $\begin{array}{c}\text { Duration of the ice periods, } \\
\text { (days) }\end{array}$ \\
\hline Average & November 28 & June 8 & 192 \\
\hline Early & November 20 & May 20 & 181 \\
\hline Late & December 10 & June 22 & 197 \\
\hline
\end{tabular}

\subsection{Annual variability of the IC values}

Analysis of the variability of this indicator in the area of the Pil'tun-Astokhskoye field for 1998-2018 is shown in Figure 3a. The long-term trend of changes in the IC values during this period is absent. The maximum values of the average IC per season were observed in the winters of 1998-1999 and 2006-2007 are 76 and 79\%, respectively. 
The minimum seasonal IC (59\%) was recorded in the season of 1997-1998. There is uneven 2-3-year alternation of extremes in the inter-annual variability of the sea-ice area.

In the north-western region, as well as in the Sea of Okhotsk as a whole, there is a clearly pronounced tendency for the decrease in the IC values by $17 \%$ during this time period (Fig. 3b). Against the background of the current global warming period, this trend appears in the Sea of Okhotsk since the late 1970s and continues to the present (Pishchal'nik et al., 2018).

It should be noted that the change in the IC characteristics has been recorded not only in reduction of its area, but also in reduction of the thickness of ice on the coastal HydroMeteoStations (Dumanskaya, 2017). Currently, there is a lack of regular data of instrumental measurements of the thickness of the drifting ice in the open sea. In the operational practice of ice service, the age characteristics (ice thickness) in accordance to deciphering features are determined by ice experts on the basis of satellite images of the visible range. Despite the fact that collections of good quality satellite images have been available for the last two decades, no systematic estimates of ice thickness have been made for them, since it's requires a lot of time and availability of trained scientists.

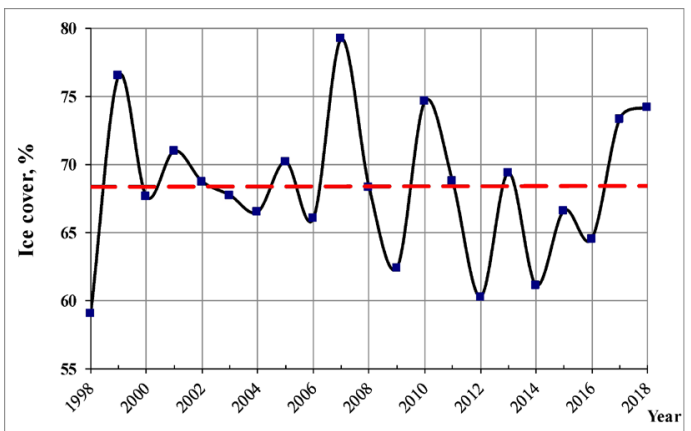

a

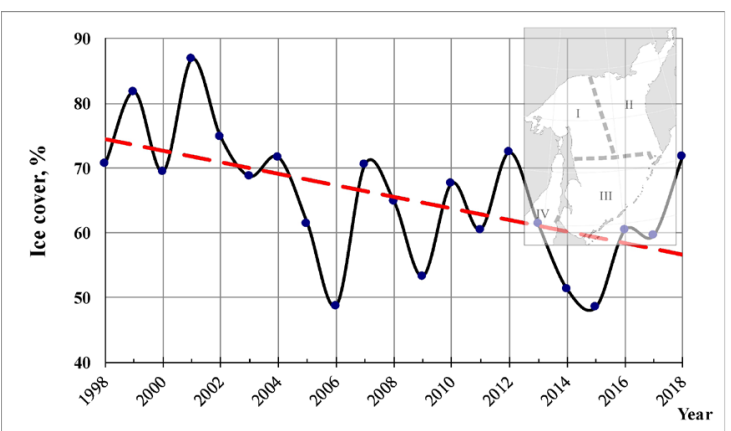

b

Fig. 3. Interannual variability of seasonal IC values: a - in the studied area of the Pil'tunAstokhskoye field; $b$ - in the north-western region of the Sea of Okhotsk (on inset it is indicated by the number I).

According to our estimates (Pishchal'nik, Minervin, 2019 in Press), the thickness of the ice pack adjacent to the north-eastern coast of Sakhalin Island has decreased by 10-15 cm compared with the beginning of the 2000s, which does not contradict to the calculations (Dumanskaya, 2017). Thus, while maintaining the warming trend in the coming decades, the thickness of the array of one-year ice, as well as their area, will significantly decrease, which will undoubtedly affect both the change in the total duration of the ice season and the timing of individual ice phases.

\subsection{Features of the annual course of IC in various types of winters}

The main task of winter typization on a given criterion (in this case on the IC) is to rank a series of observations into three (according to the types of winters allocated severe, moderate and soft) approximately equal parts, to search for patterns of variability 
of the desired parameter with other available hydrometeorological factors. From the analysis of Table 2 it follows that the allocation of types of winters in the region of a higher rank (the north-western region of the Sea of Okhotsk) is more correct. Therefore, when describing the ice situation of various phases of the development of the IC, special attention has been paid to the combination of ice conditions in the study area in the years coinciding in the typization of winters in both water areas (in bold).

Table 2

Typization of winters by severity of ice conditions for the period of 1998-2018

\begin{tabular}{|c|c|}
\hline Types of winters & Year \\
\hline \multicolumn{2}{|r|}{ Studied region of Pil'tun-Astokhskoye explored area } \\
\hline Severe & $1999,2007,2010,2018$ \\
\hline Moderate & 2000, 2001, 2002, 2003, 2004, 2005, 2006, 2008, 2011, 2013, 2015, 2016, 2017 \\
\hline Soft & $1998,2009,2012,2014$ \\
\hline \multicolumn{2}{|r|}{ Northwest region of the Sea of Okhotsk } \\
\hline Severe & $1999,2001,2002,2004,2012,2018$ \\
\hline Moderate & $1998,2000,2003,2005,2007,2008,2010,2011,2013,2016$ \\
\hline Soft & $2006,2009,2014,2015,2017$ \\
\hline
\end{tabular}

The graphs of the seasonal course of IC clearly show the differences in the peculiarities of filling with the sea ice of the studied water area (Pil'tun-Astokhskoye explored area) and the north-western region of the Sea of Okhotsk (Fig. 4a). In the Pil'tunAstokhskoye field, at the beginning of the ice formation process, the increase in the ice area in severe winters occurs evenly (Fig. 4a). In mild winters, there is the slowdown in the IC values in late November and early December, and in mild winters - in the second half of December. These fluctuations are due to characteristic time periods for cyclones to pass through the central and northern parts of the Sea of Okhotsk for different types of winters. During the period of IC destruction, sharp fluctuations in the ice cover values are observed during all types of winters, which can be explained by the limited size of the area under study (Pil'tun-Astokhskoye explored area).

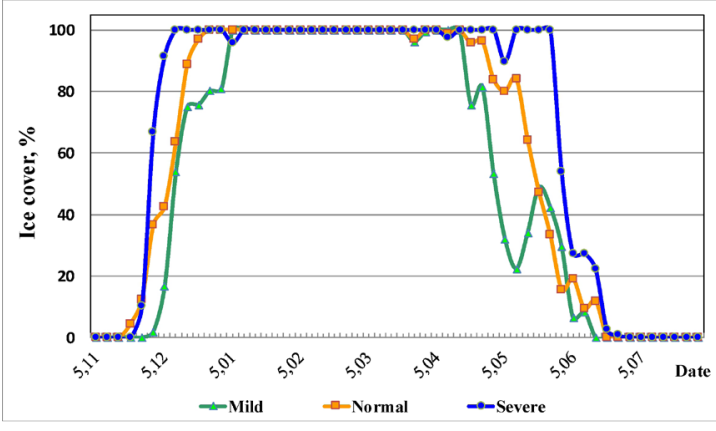

a

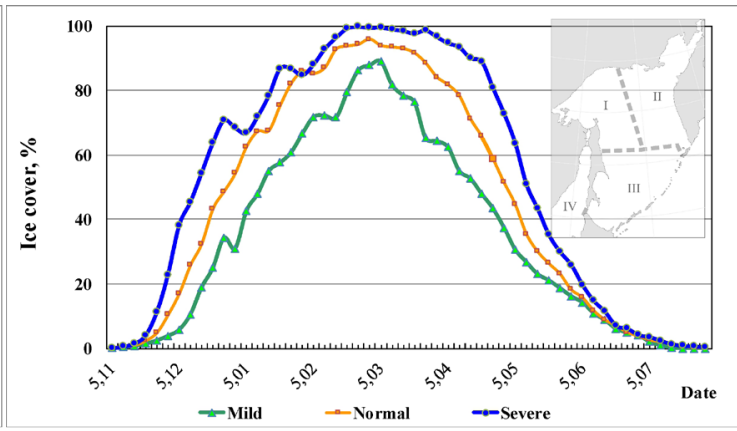

b

Fig. 4. Intra-seasonal variability of the IC at the various winter types: a - in the waters of the Pil'tun-Astokhskoye field; $b$ - in the north-western region of the Sea of Okhotsk (on the inset is indicated by the number I). 
For the north-western region, on the contrary, there are sharp fluctuations in the IC values at the phase of its increase for all types of winters. This is due to the influence of deep cyclones going to the northern part of the Sea of Okhotsk which is filled with nilash and young ice at the beginning of the ice season. Nilash (ice thickness up to $10 \mathrm{~cm}$ ) and young ice (ice thickness $10-30 \mathrm{~cm}$ ) can multiply reduce the area occupied by them as a result of compression by the wind. At the phase of destruction of the massif, such sharp fluctuations in the ice cover values for all types of winters have not been observed, since the one-year ice (ice thickness is 30-70 cm), which dominate the ice mass in the spring period, has a much lower degree of compression damage due to wind.

\subsection{Intra-seasonal variability of ice concentration}

It is important to note that for the Pil'tun-Astokhskoye field, as well as for the Sea of Okhotsk as a whole, the ice concentration is not a representative characteristic of the state of IC status assessment. Due to the features the IC as described above, the ice formation occurs intensively and continuously from November to April and any discharges in the IC are quickly filled with initial types of ice which are recorded as ice according to the results of visual and satellite observations. This is clearly seen in the diagram (Fig. 5) the very close ice prevails at the stage of formation and the maximum development of the IC. The average for the season frequency of very close ice is $85 \%(9-10 / 10)$, close ice $(7-8 / 10)-7 \%$, open ice $(4-6 / 10)-4 \%$ and very open ice $(1-3 / 10)-4 \%$.

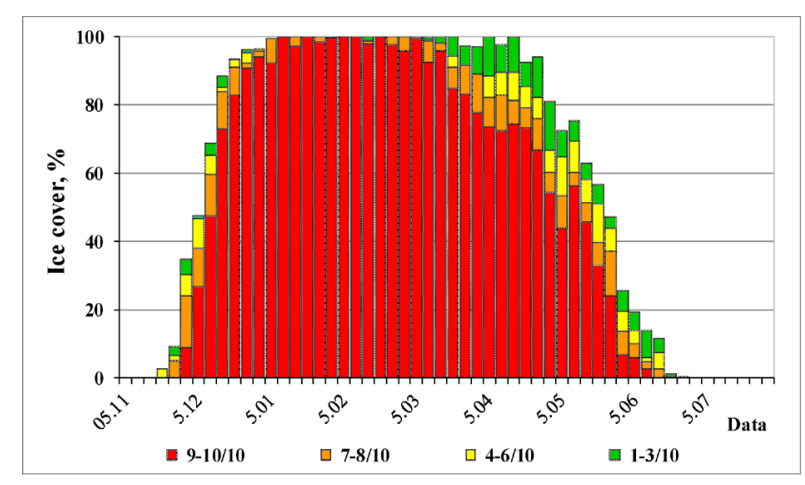

Fig. 5. Intra-seasonal ice concentration in the IC for the period of 1998-2018 in the Pil'tunAstokhskoye field.

Analysis of the calculated data shows that the investigated water area of the Pil'tunAstokhskoye field is maximally filled with ice from December to April. With the minimum IC value, the complete filling with ice (90-100\%) is observed from January to March. From this, it follows that the highest probability of natural formation of OWS exists in November, May, June, and partly in December (Table 3).

Table 4 Mean monthly values of the IC (\%) within the studied area in November-June for 1998-2018

\begin{tabular}{|l|c|c|c|c|c|c|c|c|}
\hline Month & XI & XII & I & II & III & IV & V & VI \\
\hline Average & 8 & 82 & 100 & 100 & 99 & 94 & 57 & 8 \\
\hline Maximal & 38 & 100 & 100 & 100 & 100 & 100 & 97 & 29 \\
\hline Minimal & 0 & 24 & 98 & 100 & 90 & 62 & 6 & 0 \\
\hline
\end{tabular}




\section{Features of the IC development for different ice phases}

It is proposed to distinguish two types of OWS formation - natural and artificial. In order to understand the mechanism of natural OWS formation in the studied water area, it is advisable to divide the ice season into four time periods - the phases of the development of the IC with characteristic ice conditions.

Phase I - the beginning of ice formation (formation of the IC): from the date of the first ice appearance in the coastal strip until the formation of polynya (average dates from November 28 to December 31). During this period, the IC is represented by the initial types of ice - frazil ice, grease ice, slush and shuga. Since there is still no solid IC, weak wind waves develop on ice-free parts of the water area which, together with swell waves, creates conditions for the formation of pancake ice (Fig. 6). By mid-December, the prevailing concentration of the pancake ice is $4-6$ points, so natural OWS in the area under study are quite sufficient for local gathering and eliminating oil spilled on the surface of the water. At the end of this period, the ice concentration reaches 10/10 (Fig. 7).

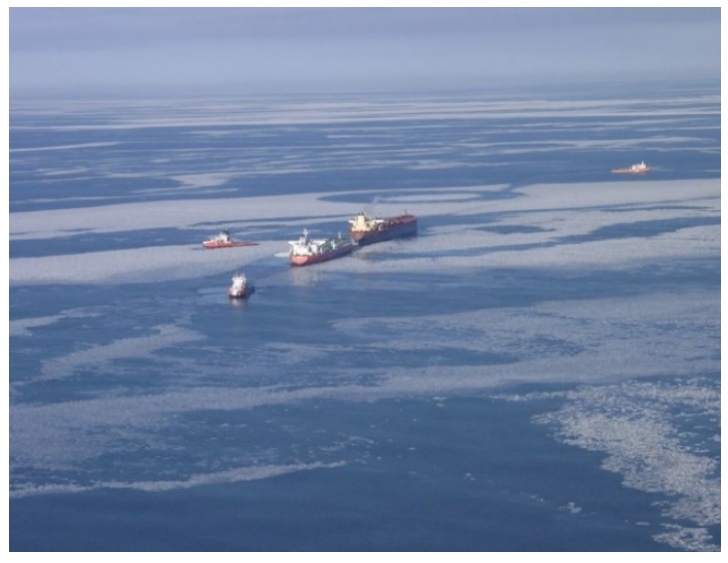

Fig. 6. Sparse pancake ice zone. Download supertanker. Photo taken from a helicopter 11.28.2000.

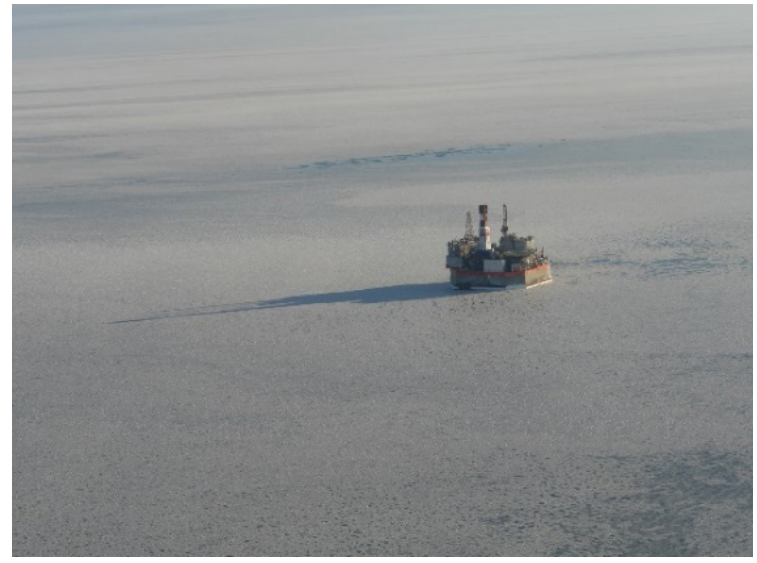

Fig. 7. Solid pancake ice during the period of change of the tide phase (OWS behind the platform is not formed). Snapshot from a helicopter 10.12.2006.

The stage of formation of polynya is completed after the formation of older ice belt on its eastern border which prevents the spread of pancake ice to the east and south. Driving under the influence of the winter monsoon, young ice breaks down along its boundary as a result of deformation. At the same time, solid IC of nilash ices forms in the vacant space of open water along the coast of the island. Usually the process of replacing pancake ice with nilash ice in the polynya takes place within 5-10 days.

Phase II - the polynya is filled with 3-10 cm thick nilash ice (Fig. 8-9). The shape is a solid, slightly deformed IC which is usually observed from January 1 to March 5. The image from the satellite clearly shows the trail formed in the IC behind the MISP as a result of its drift (artificially formed by the OWS). If at the tidal phase wind directions and currents coincide, the OWS behind the platform may extend over the first tens of kilometers (in Fig. 8, the diameter of the circle highlighted in yellow is $10 \mathrm{~km}$ ). In the ebb 


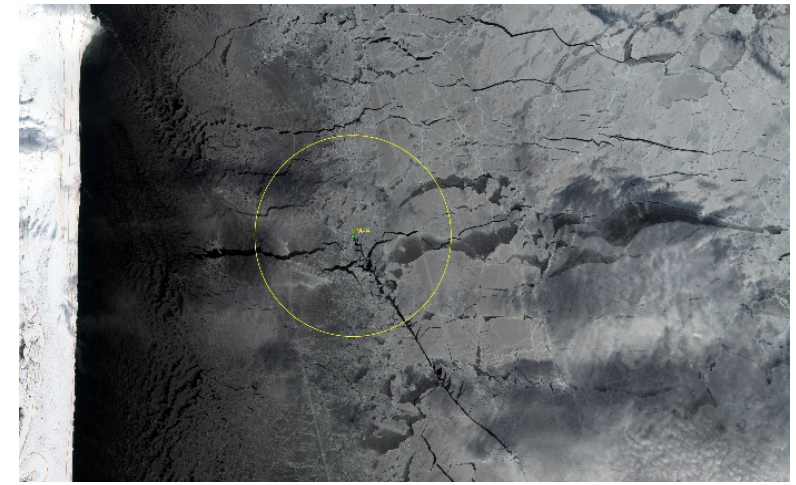

Fig. 8. Tidal trail in nilash ice behind the MISP PA-B. Snapshot of Sentinel-2, 02.15.2019.

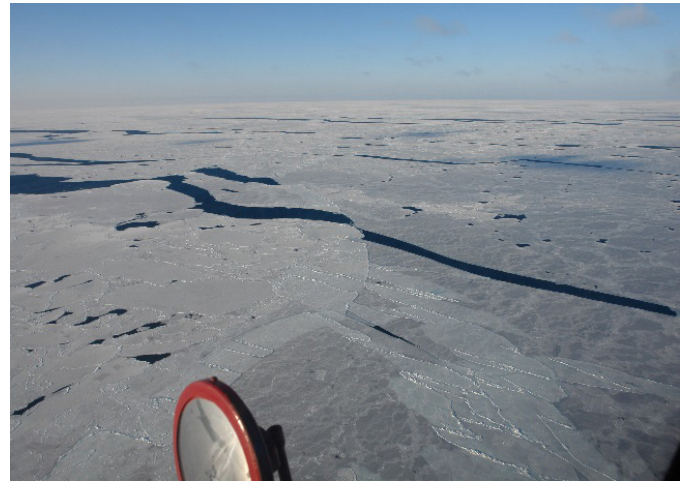

Fig. 9. A typical view of nilash ice in the polynya. Snapshot from a helicopter, 17.12. 2006.

phase, the tidal current is directed to the north, i.e. against the direction of the drift of the IC or at an angle to it. In such situations, an artificially formed OWS could be filled with ice almost immediately after the MISP or at some distance from it.

The prevailing ice concentration is 10 points but usually there is no compression. As in phase I, the polynya could be completely closed for several hours under the influence of the winds of the east rumba. Nilash ice in the polynya will be destroyed and pressed to the shore in the form of brash ice and very close young or first-year ice will move in their place. After changing the direction of the wind the nilash ice is restored in the newly forming polynya in a few hours.

The thickness of the ice in the polynya, as well as its layering, increases with distance from the coast. The thickness of the ice depends on the time the ice is in the polynya, i.e. on its size. During periods of maximum development of polynya, the thickness of the ice on the eastern border reaches $12-17 \mathrm{~cm}$ and on the southern $-15-25 \mathrm{~cm}$ while the ice layering near the coast does not exceed $1-2 / 10$ and on the eastern and southern border of the polynya it can reach 7-10/10. Taking into account the direction of the general drift of ice in the ice massif, at a stable synoptic situation, oil spilled on the IC, or on the OWS and captured by the current under the ice, will accumulate in a few days along the southeastern border of the polynya.

Phase III - the period of filling the area under study with very close and solid first-year ice after the monsoon changes direction. As the winter monsoon weakens and summer monsoon forms, the speed of general ice drift in the Sea of Okhotsk noticeably decreases and with the onset of the summer monsoon the direction of the drift changes to the opposite (from the south-east to north-west). As a result, the massif of first-year ice on East Sakhalin is pressed to the shore during the period from the second half of March to the end of April. This is the most difficult period for the fleet serving the oil and gas production platforms and for responding to oil spills, since there is practically no natural OWS and artificial creation of OWS is almost impossible due to the constant compression of ice. At the beginning of phase III the IC is represented by large and giant fields and fragments of ice fields. And at the end it is represented by fragments of ice fields, smallsized ice and brash ice of very close and continuous first-year thin ice (thickness 30 
$70 \mathrm{~cm}$ ) with inclusion of up to 3-4 points first-year ice of average thickness $(70-120 \mathrm{~cm})$. Oftentimes long periods of weak ice compression in the massif are recorded (Fig. 10-11).

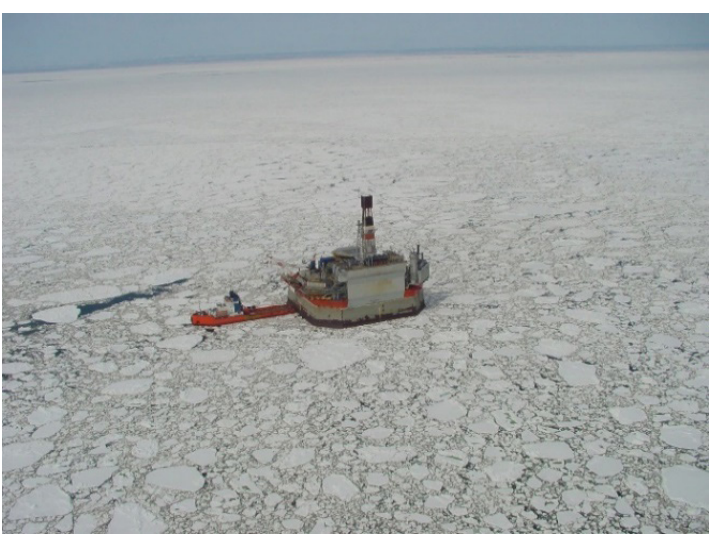

Fig. 10. The characteristic state of IC on the MISP PA-A. Snapshot from a helicopter 08.05.2006.

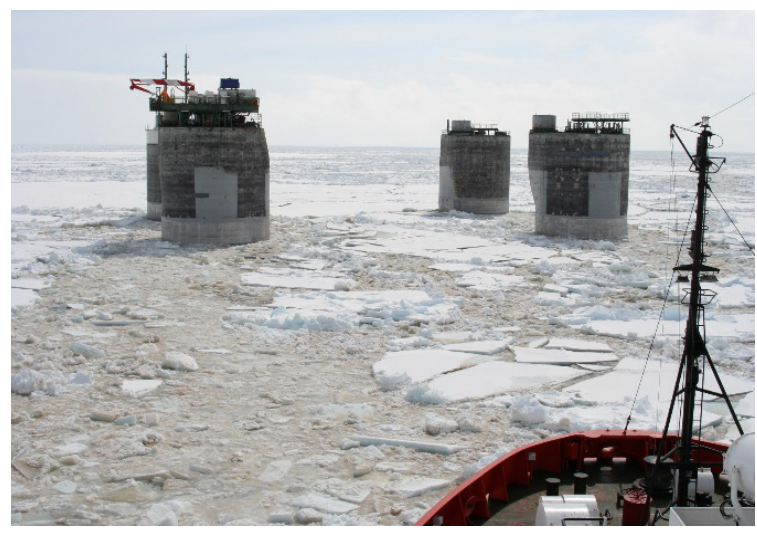

Fig. 11. Continuous first-year ice on phase III near the base of the MISP PA-B. Snapshot from a ship 04.04.2001.

Phase IV is the period of IC destruction (average dates - from May 1 to June 9, Table 4). The active thermal destruction of sea ice begins in May. At this time, the speed of the East Sakhalin Current on the surface decreases to zero values [Pishchal'nik et al., 2014]. The average wind speed of south-east rumba does not exceed 5-6 m / s. Collapsing ice sits deep in the water and is slightly exposed to wind influence. Array of ice moves away from the coast, its concentration decreases to $4-6 / 10$. The prevailing ice forms are broken ice (ice cake) and brash ice which often get stuck into strips of very close ice (Figures 12-13). Ice rupture ranges from 2 to $4 / 10$.

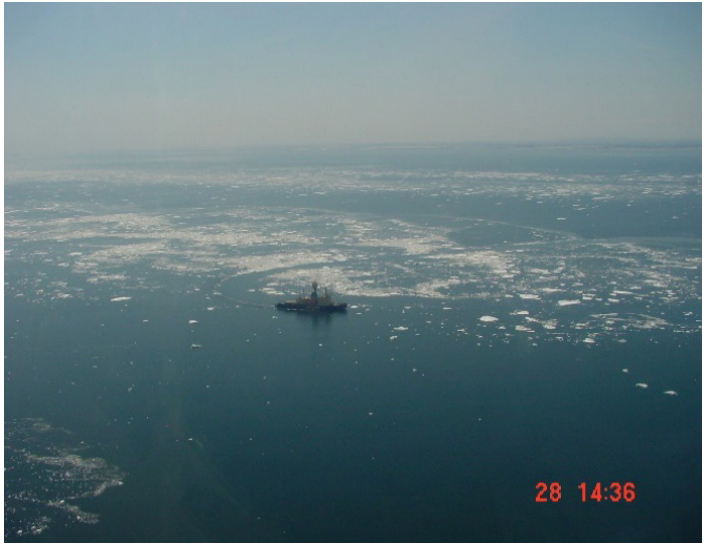

Fig. 12. The characteristic state of the IC at the phase of destruction. 04.28.2005.

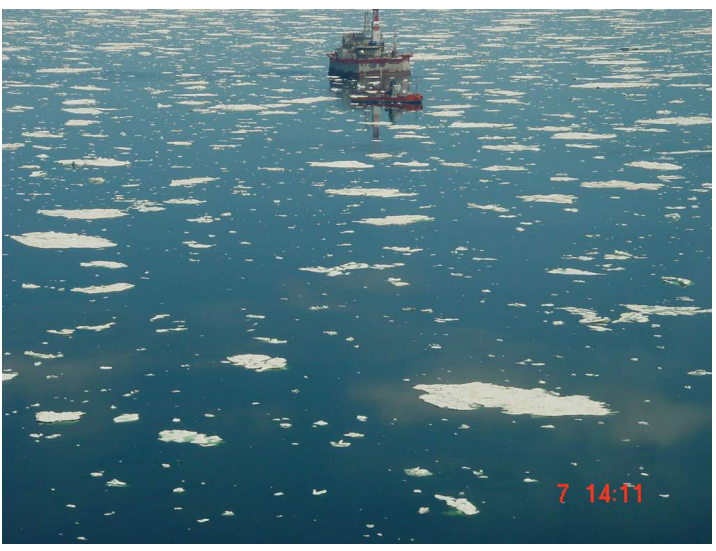

Fig. 13. View of the MISP PA-A from a helicopter. 07.06.2002 (the tide shift phase).

Usually in June the rare ice is observed which are the remains of hummocks (floebergs) and forms of ice cakes with destruction of at least 4 points. Under the wind influence sometimes they go astray. Ice thickness varies from 0.5 to $2-3 \mathrm{~m}$. The latest date of complete clearing of the study area from ice was observed on June 22 in 2003, 2011 and 2018. 
Table 4 Onset dates of characteristic phases of the IC development in the waters of the Pil'tunAstokhskoye field in 1998-2018

\begin{tabular}{|c|c|c|c|c|}
\hline $\begin{array}{c}\text { Phase I } \\
\text { Formation of IC }\end{array}$ & $\begin{array}{l}\text { Phase II } \\
\text { Polynya }\end{array}$ & $\begin{array}{c}\text { Phase III } \\
\text { First-year ice }\end{array}$ & $\begin{array}{c}\text { Phase IV } \\
\text { Destruction of IC }\end{array}$ & $\begin{array}{c}\text { Date of complete } \\
\text { disappearance }\end{array}$ \\
\hline \multicolumn{5}{|c|}{ Average data } \\
\hline November 28 & December 31 & March 5 & April 30 & June 9 \\
\hline \multicolumn{5}{|c|}{ Ice concentration, $1 / 10$} \\
\hline $5-8$ & $9-10$ & $9-10$ & $4-6$ & - \\
\hline \multicolumn{5}{|c|}{ Thickness of IC, $\mathrm{cm}$} \\
\hline $2-12$ & $4-14$ & $30-90$ & $30-90$ & - \\
\hline \multicolumn{5}{|c|}{ Early data } \\
\hline November 18 & November 14 & March 1 & April 23 & May 13 \\
\hline \multicolumn{5}{|c|}{ Ice concentration, $1 / 10$} \\
\hline $4-7$ & $9-10$ & $9-10$ & $4-5$ & - \\
\hline \multicolumn{5}{|c|}{ Thickness of IC, $\mathrm{cm}$} \\
\hline $2-10$ & $4-12$ & $25-80$ & $30-90$ & - \\
\hline \multicolumn{5}{|c|}{ Late data } \\
\hline December 10 & January 13 & March 15 & May 8 & June 22 \\
\hline \multicolumn{5}{|c|}{ Ice concentration, $1 / 10$} \\
\hline $5-9$ & $9-10$ & $9-10$ & $4-7$ & - \\
\hline \multicolumn{5}{|c|}{ Thickness of IC, $\mathrm{cm}$} \\
\hline $3-13$ & $4-16$ & $35-100$ & $35-100$ & - \\
\hline
\end{tabular}

The most important results of the analysis for solving the problem of collecting and eliminating oil on the surface in the OWS include the following:

- the earliest and latest dates in the beginning of ice formation and complete cleaning from ice do not always correspond to the winter types. For an adequate assessment of ice conditions, it is desirable to use at least two features of the actual ice situation;

- at any phase of the IC development during the passage of deep baric formations through the central and northern regions of Sakhalin Island, there may be a short-term both complete clearing from ice and complete closure by ice of the studied water area;

- at the present stage of information age, it is not possible to determine the type of winter in the Sea of Okhotsk by the quantitative features of the ice situation at the beginning of the ice season. During one season in different regions of the sea the IC development can occur simultaneously in all major types of winters (Pishchal'nik et al., 2017).

\section{Experience of creating artificial spaces of open water in the IC in the waters of the Pil'tun-Astokhskoye field}

During the ice service period for offshore operations in the MISP PA-A area (formerly Molikpaq) in the first phase of the Sakhalin-2 Project (2000-2008) to ensure the safety of offshore operations when loading supertankers that do not have an ice class, 
lowering (in the autumn) on the bottom and the rise from the bottom (in the spring) of a single-anchor jetty, as well as for servicing diving work on the underwater pipeline, there was often a need to artificially create and maintain an OWS. The technology of the process of creating and maintaining OWS, depending on ice conditions, the phase of IC development and the task set, may be different but the fundamental approaches to their solution are the same and consist in the following:

- planning the execution of works with the most efficient use of the time of the tidal cycles;

- provision of maritime operations with a sufficient number of ice-class vessels taking into account the development phase of the IC;

- development of technology for safe operation under specific weather ice conditions for each MISP.

From the analysis of the research results it follows that for the water area of the Pil'tun-Astokhskoye field there are two time periods when OWS are formed naturally. These are the early stage of ice formation from the moment of the first ice appearance on November 18 until December 15-20 and the stage of destruction of the IC from May 15 to the moment of complete purification the study area from the ice on June 22. In the period from December 20 until the completion of the selected phase II (until March 5-10) the studied water area is located in the polynya zone which is formed and maintained by the winter monsoon. During the period of the existence of a polynya, very close and continuous nilash ice prevails in it and where it is quite possible to create OWS and maintain it artificially to accomplish the task of eliminating an oil spill. It should be borne in mind that:

- the maximum effect of creating an artificial OWS is achieved at the tide phase which lasts $\sim 11$ hours. From the experience of observations it follows that the length of the OWS at high tide strongly depends on the direction and speed of the wind. In the initial period of the low-flow phase the track from the MISP will quickly close due to residual IC drift. Under a certain combination of conditions for the formation of a tidal ellipse, the artificially created OWS behind the MISP could return to the starting point;

- at the late stage of the existence of open water (from February 15) and the initial stage of the period of destruction of the IC (from May 15), special attention should be paid to ensuring the escort of specialized vessels (which usually do not have ice class) to the open water through a belt of heavy one-year ice;

- during phase III (from March 10-15 to May 5-10) the creation of artificial OWS is unlikely due to the concentration of the array of very cohesive one-year ice along the coast of East Sakhalin which is observed on annual basis when the monsoon circulation changes.

An example of creating an artificial OWS in phase II in the presence of a continuous IC in the polynya represented by nilash ice is shown in Fig. 14 and 15. In this case, the purpose of creating OWS was to ensure the safe loading of supertanker with oil. The sequence of vessels can be arranged as follows. 


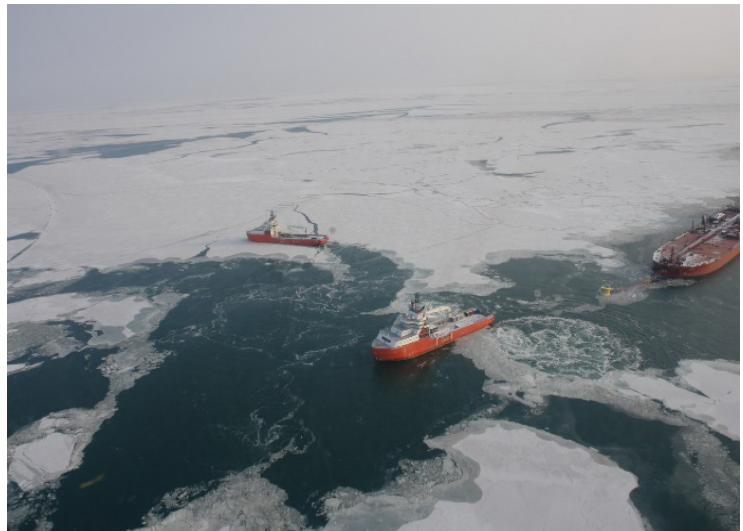

Fig. 14. Artificial creation of OWS to ensure the safety of the tanker bunkering operation. 13.12.2006.

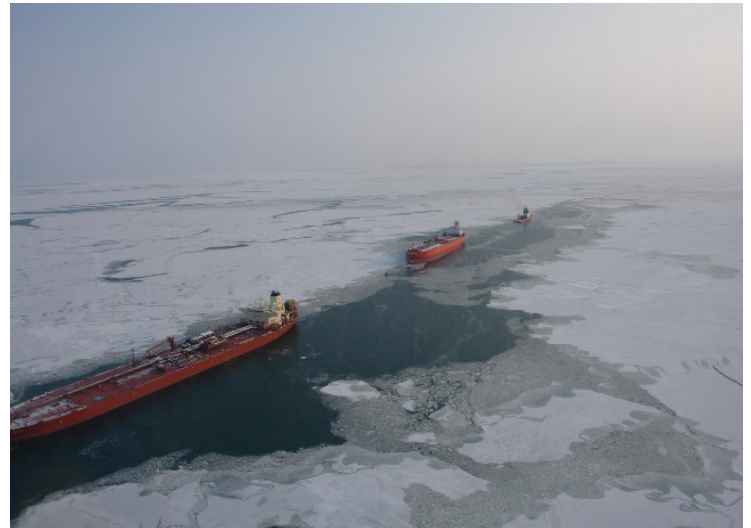

Fig. 15. The order of the courts when performing operations (continued). A snapshot from a helicopter 13.12.2006.

The supplier (specialized supply vessel) heads the caravan of ships. It is located in the channel formed behind the platform as a result of the IC drift and is positioned at a distance of the hull in front of the single anchor berth to which the floating oil storage facility is moored. Its propeller speakers (azipods) are deployed almost perpendicular to the hull of the vessel and the engines operate at full capacity. The wake stream spreads the IC and forms steady OWS on the tidal current. Behind the supplier the floating oil storage "Okha" is located with a displacement of 164 thousand tons (the length of the vessel is $216 \mathrm{~m}$ ). This is followed by a supertanker with a displacement of 100 thousand tons and another supplier closes the ship's caravan which holds the supertanker with a tension of not less than 20 tons in order to avoid twisting and tearing of the cargo hose. Thus, an artificial OWS with a length of $\sim 1 \mathrm{~km}$ and a width of $>100 \mathrm{~m}$ is created. The bunkering time of the supertanker of the specified displacement does not exceed 10-11 hours, so the operation usually fits into one tidal phase. It should be noted that with this arrangement the ships' caravan could be deployed when the direction of the tide changes while maintaining the tension of the mooring cables and the bunker hose.

An example of an artificial creation of OWS in phase IV is shown in Fig. 16. The goal was to ensure the safety of marine operation to carry out routine work by divers on underwater pipeline. The length of the pipeline from the platform to the single-anchor berth is $\sim 2 \mathrm{~km}$. The first supplier from the platform was installed on four anchors and, simultaneously changing the length of the feeding and bow anchor chains, was positioned above the oil pipeline with accuracy of tens of centimeters. In the hull of the vessel there was a special mine for the descent of divers and equipment.

To accomplish the main task - to prevent the impact of ice formations on the hull and anchor chains - the order of placement of vessels should be as follows:

- an icebreaker is located on the first line, which determines the direction of movement of large ice formations using radar, calculates the trajectory of their movement and, if there is a likelihood of them entering the work sector, then destroys them with their hull (Fig. 17). Another supplier is positioned on the second line and, as described above, the wake forms wedge. On the third line ice-class towboats push the hull off the remnants 
of broken ice formations that may affect the anchor chains or the vessel itself (Fig. 16). The fourth line contains the object the ice service - a vessel that performs diving work.

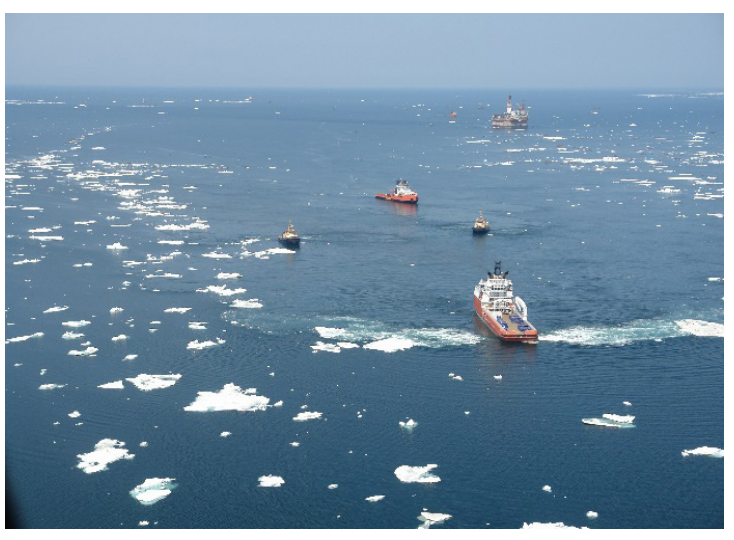

Fig. 16. Creation of a OWS in front of a vessel standing on 4 anchors. 09.06.2007.

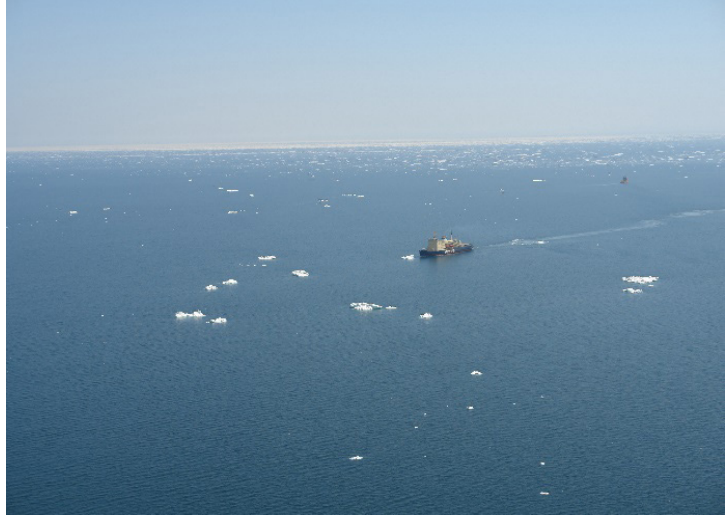

Fig. 17. Destruction of ice formations by the icebreaker hull. 09.06.2007.

\section{Conclusions}

This paper analyzes the conditions of formation of OWS in the IC in the waters of the Pil'tun-Astokhskoye field on the basis of aeronautical, marine, and satellite observations and personal experience of the authors. The study found the following:

- in the modern period of warming, which has been observed in the Sea of Okhotsk since 1980, the variability of ice processes is such that during a single ice season each of the stages of IC development (formation, maximum development and destruction of ice) in different regions of the sea can develop in different types of winters. Accurate forecast of the type of winter at all of the listed stages with the present level of knowledge is currently not possible;

- when developing long-term solutions, it is necessary to take into account the warming trend. If it is preserved in the coming decades, the thickness of the massif of first-year ice, as well as its area, may significantly decrease, which will affect both the change in the duration of the ice season and the timing of the onset of individual ice phases;

- the earliest date of the ice appearance in the studied area was observed on November 18 , the latest date of complete clearing from ice - June 22. Thus, the maximum possible duration of the IC is 216 days;

- for the water area of the Pil'tun-Astokhskoye field, the characteristic elements of the ice regime are a uniform increase in the IC during the development phase and its abrupt fluctuations during the destruction phase of the ice massif;

- according to the characteristic combination of ice conditions, four phases of the IC development were identified in the studied area:

- phase I - the beginning of ice formation from the date of the first ice appearance in the coastal strip until the formation of polynya (average dates from November 28 to December 30). The predominant forms are pancake ice with thickness of 3-12 cm; 
- phase II - polynya filled with solid nilash ice 3-10 cm thick (average dates from December 31 to March 4);

- phase III - closed and very closed first-year ice (average dates from March 5 to April 29). The prevailing forms are large fields, fragments, and ice cake, from 30 to $130 \mathrm{~cm}$ thick;

- phase IV - destruction of the IC line (average time from April 30 to June 8). The predominant forms are fragments of ice fields, broken and small cake ice, with a thickness of 30 to $130 \mathrm{~cm}$;

- at all of the listed phases of the IC development, a short-term (from tens of hours to several days) both a complete purification and a complete closure of the studied water area are possible.

Natural OWS are observed in the IC of the study area at phases I (NovemberDecember) and IV (May-June). During these periods, as well as in phase II (JanuaryFebruary), there are methods and technical capabilities for artificial OWS formation. Scenario options of using the layered ice control system are presented. However, it is necessary to take into account the fact that the passage to the water area of the Pil'tunAstokhskoye field of specialized vessels without ice class at phases II-IV may incur great risks.

In phase III (from 10-15 March to 5-10 May), the creation of artificial OWS is unlikely due to the concentration of an array of very closed first-year ice with inclusion of 1-3 points of first-year ice of average thickness along the coast of East Sakhalin. Therefore, the development of methodology for conducting oil spill response operations in stage III should be the subject of further research.

This research was performed in the framework of state assignment - theme No. 5.9510.2017/8.9(Sakhalin State University, Russia) and theme No. 0149-2019-0005 (Shirshov Institute of Oceanology, RAS).

\section{References}

Astaf'yev V.N., Surkov G.A., and Truskov P.A. Torosy i stamukhi Okhotskogo moray (Hummocks and Grounded hummocks of the Sea of Okhotsk). St. Petersburg: Progress-Pogoda, 1997, (In Russian).

Dumanskaya I.O. Ledovyye usloviya morey aziatskoy chasti Rossii (Ice conditions of the seas of the Asian part of Russia). Moskva: Obninsk: IG - SOCIN, 2017, (In Russian).

Minervin I.G., Romanyuk V.A., and Pishchal'nik V.M. Zoning the Ice Cover of the Sea of Okhotsk and the Sea of Japan. Herald of the Russian Academy of Sciences, 2015, Vol. 85, No. 2, pp. 132-139. Pleiades Publishing, Ltd., 2015, doi: 10.1134/S1019331615010049.

Monin A.S., Kamenkovich M.N., and Kort V.G. Izmenchivost' Mirovogo okeana (The variability of the oceans). St. Petersburg: Gydrometeoizdat, 1974, (In Russian).

Pishchal'nik V.M., Pokrashenko C.A., Leonov A.V., and Gal'tsev A.A. Osobennosti razvitiya ledyanogo pokrova Okhotskogo morya v 2001-2006. (Features of the development of the ice cover of the Sea of Okhotsk in 2001-2006. Sbornik statey REA No. 1 «Ekologicheskiye aspekty osvoyeniya neftegazovykh mestorozhdeniy», "Environmental aspects of 
the development of oil and gas fields." Vladivostok: Dal'nauka, 2009, pp. 185-197, (In Russian).

Pishchal'nik V.M., Arkhipkin V. S., and Leonov A.V. Reconstruction of the Annual Variations of Thermohaline Characteristics and Water Circulation on the Northeastern Sakhalin Shelf. Water Resources, 2014, Vol. 41, No. 4, pp. 385-395, doi: 10.1134/S0097807814040113.

Pishchal'nik V.M., Romanyuk V.A., Minervin I.G., and Batukhtina A.S. Analiz dinamiki anomaliy ledovitosti Okhotskogo morya v period s 1882 po 2015 (Analysis of the dynamics of the ice cover anomalies of the Sea of Okhotsk in the period from 1882 to 2015). Izv. TINRO, 2016, Vol. 185, pp. 228-239, (In Russian).

Pishchal'nik V.M., Minervin I.G., and Romanyuk V.A. Analysis of Variations in the Ice Regime in Individual Regions of the Rea of Okhotsk during the Warming Period. Herald of the Russian Academy of Sciences, 2017, Vol. 87, No. 3, pp. 237-248. Pleiades Publishing, Ltd., 2015, doi: 10.1134/S1019331617030042.

Pishchal'nik V.M. and Minervin I.G. Analiz rezul'tatov raschota ob"yoma l'da v Okhotskom more na osnove dannykh distantsionnogo zondirovaniya Zemli (Analysis of the results of calculating the volume of ice in the Sea of Okhotsk based on remote sensing data). Izv. TINRO, 2019, (In press), (In Russian).

Pokrashenko S.A., Truskov P.A., and Yakunin L.P. Issledovaniye dreyfa l'da na shel'fe o. Sakhalin s pomoshch'yu metodov radiolokatsii (The study of ice drift on the shelf. Sakhalin using radar methods). Tr. DVNII, 1987, Vol. 37, pp. 49-52, (In Russian).

Romanyuk V.A., Pishchal'nik V.M., and Minervin I.G. Issledovaniye vliyaniya srokov smeny sezonov na ledovitost' Okhotskogo i Yaponskogo morey (Study of the influence of seasons on the ice cover of the Sea of Okhotsk and the Sea of Japan), Fizika geosfer: Sed'moy Vserossiyskiy Simpozium, September 5-9, 2011. Vladivostok: Dal'nauka, 2011, pp. 218224, (In Russian).

Romanyuk V.A., Pishchal'nik B.M., Bobkov A.O., and Minervin I.G., Osnovnyye printsipy raboty programmnogo kompleksa «LYOD» (Basic Principles of Operation of the Program «ICE», Fizika geosfer: IX-th Vserossiyskiy simpozium, August 31-September 4. 2015. Vladivostok: Dal'nauka, 2015, pp. 556-561, (In Russian).

Svidetel'stvo o gosudarstvennoy registratsii programmy dlya EVM № 2015660472. Programmnyy kompleks dlya rascheta ploshchadi ledyanogo pokrova v Okhotskom i Yaponskom moryakh po dannym DZZ (PK «LYOD») (Certificate of state registration of computer programs No. 2015660472. Software complex for calculating the ice cover in the Sea of Okhotsk and the Sea of Japan according to remote sensing data (LYOD PC). Authors: Pischal'nik V.M., Bobkov A.O. and Romanyuk V.A. State date registration in the Register of computer programs October 1, 2015, (In Russian).

http://www.data.jma.go.jp.

https://worldview.earthdata.nasa.gov.

https://apps.sentinel-hub.com. 


\title{
АНАЛИЗ УСЛОВИЙ ФОРМИРОВАНИЯ ПРОСТРАНСТВ ОТКРЫТОЙ ВОДЫ ЗА МОРСКИМИ ПЛАТФОРМАМИ ДЛЯ УСТРАНЕНИЯ РАЗЛИВОВ НЕФТИ
}

\author{
Пищальник В.М. ${ }^{1}$, Трусков П.А. ${ }^{2}$, Соломатин С.В. ${ }^{2}$, Романюк В.А. ${ }^{3}$, \\ Леонов А.B. ${ }^{4}$
}

${ }^{1}$ Сахалинский государственный университет, 693008. Южно-Сахалинск, ул. Ленина 290. e-mail: vpishchalnik@rambler.ru

${ }^{2}$ Сахалин Энерджи Инвестмент Компании, Лтд.; 123242, Москва, Новинский бульвар, 31 ${ }^{3} \mathrm{OOО} \mathrm{«РН-СахалинНИПИморнефть»;} \mathrm{693000,} \mathrm{Южно-Сахалинск,} \mathrm{Амурская} \mathrm{ул.,} 53$ ${ }^{4}$ Институт океанологии им. П.П. Ширшова РАН, 117997, Москва, Нахимовский проспект, д. 36

Статья поступила в редакцию 15.08.2019, одобрена к печати 21.11.2019

\begin{abstract}
Первая морская ледостойкая стационарная платформа Пильтун-Астохская-А (МЛСП ПА-А) была установлена на северо-восточном шельфе о. Сахалин более 20 лет назад. В настоящее время в прибрежных акваториях работает пять МЛСП (ПА-А, ПА-Б, ЛУН-А, Орлан и Беркут) и активно обсуждаются планы по обустройству новых месторождений углеводородов. Продолжительность ледового периода в данном районе Охотского моря колеблется от 181 до 197 суток и вопросы планирования мероприятий по предотвращению и борьбе с возможными масштабными разливами нефти в ледовый период имеют особую актуальность. В работе приведены результаты исследования условий формирования пространств открытой воды (ПОВ) в ледяном покрове за МЛСП, полученные на основе данных авиационных, судовых и спутниковых наблюдений, а также практического опыта работ по управлению ледовой обстановкой в рамках проекта «Сахалин-2» в 1999-2008 гг. Учет особенностей образования ПОВ может существенно повысить эффективность реагирования на нефтяное загрязнение при наличии ледяного покрова, например, путем устранения нефти в следе, образующемся за МЛСП в результате дрейфа льда и снизить нагрузки на морскую среду. Предложенный методологический подход искусственного создания ПОВ может быть реализован на акваториях замерзающих и арктических морей, омывающих берега России, где ведется разработка морских месторождений углеводородов. При этом особое внимание для каждой конкретной МЛСП должно быть уделено учету локальных ледовых условий при разработке вопросов безопасности проведения подобных мероприятий.
\end{abstract}

Ключевые слова: пространства открытой воды, сезонная ледовитость, ледовые условия, ледовые фазы, спутниковые снимки, эффективность реагирования на загрязнение нефтью морских вод при наличии ледяного покрова.

\section{Литература}

Астафьев В.Н., Сурков Г.А., Трусков П.А. Торосы и стамухи Охотского моря. СПб.: Прогресс-Погода, 1997.

Думанская И.О. Ледовые условия морей азиатской части России. М.: Обнинск: ИГСОЦИН, 2017.

Минервин И.Г., Романюк В.А., Пищальник В.М., Трусков П.А., Покраменко С.А. 
Районирование ледяного покрова Охотского и Японского морей // Вестник РАН, 2015. T. 85. № 3. C. 209-217. DOI: 10.7868/S0869587315010119.

Монин А.С., Каменкович М.Н., Корт В.Г. Изменчивость Мирового океана. Л.: Гидрометеоиздат, 1974.

Пищальник В.М., Покрашенко С.А., Леонов А.В., Гальцев А.А. Особенности развития ледяного покрова Охотского моря в 2001-2006 гг. // Сборник статей РЭА №1 «Экологические аспекты освоения нефтегазовых месторождений». Владивосток: Дальнаука, 2009. С. 185-197.

Пищальник В.М., Архипкин В.С., Леонов А.В. Восстановление годового хода термохалинных характеристик и циркуляции вод на северо-восточном шельфе Сахалина // Водные ресурсы. 2014. T. 41. № 4. C. 362-374. DOI: 10.7868/S0321059614040129.

Пищальник В.М., Романюк В.А., Минервин И.Г., Батухтина А.С. Анализ динамики аномалий ледовитости Охотского моря в период с 1882 по 2015 г. // Изв. ТИНРО. 2016. T. 185. C. 228-239.

Пищальник В.М., Минервин И.Г., Романюк В.А. Анализ изменений ледового режима в отдельных районах Охотского моря в период потепления // Вестник РАН. 2017. Т. 87. № 5. C. 429-440. DOI: 10.7868/S0869587317050024.

Пищальник В.М., Минервин И.Г. Анализ результатов расчёта объёма льда в Охотском море на основе данных дистанционного зондирования Земли // Изв. ТИНРО. 2019. (В печати).

Покрашенко С.А., Трусков П.А., Якунин Л.П. Исследование дрейфа льда на шельфе о. Сахалин с помощью методов радиолокации // Труды ДВНИИ. 1987. Вып. 37. C. $49-52$.

Романюк В.А., Пищальник В.М., Минервин И.Г., Дорофеева Д.В., Гальщев А.А. Исследование влияния сроков смены сезонов на ледовитость Охотского и Японского морей // Физика геосфер: Седьмой Всероссийский симпозиум, 5-9 сентября 2011 г., г. Владивосток, Россия: мат. докл. / Учреждение Российской академии наук Тихоокеанский океанологический институт им. В.И. Ильичева Дальневосточного отделения РАН. Владивосток: Дальнаука, 2011. С. 218-224.

Романюк В.А., Пищальник В.М., Бобков А.О., Минервин И.Г. Основные принципы работы программного комплекса «ЛЁД» // Физика геосфер: 1Х-й Всероссийский симпозиум, 31 августа - 4 сентября 2015 г., г. Владивосток, Россия: мат. докл. / Учреждение Российской академии наук Тихоокеанский океанологический институт им. В.И. Ильичева Дальневосточного отделения РАН. Владивосток: Дальнаука, 2015. C. $556-561$.

Свидетельство о государственной регистрации программы для ЭВМ № 2015660472. Программный комплекс для расчета площади ледяного покрова в Охотском и Японском морях по данным ДЗЗ (ПК «ЛЁД»). Авторы: Пищальник В.М., Бобков А.О., Романюк B.A. Дата гос. регистрации в Росреестре программ для ЭВМ 01 октября 2015 г.

http://www.data.jma.go.jp.

https://worldview.earthdata.nasa.gov.

https://apps.sentinel-hub.com. 